EL MUHASABA: Jurnal Akuntansi (e-Journal)

Volume 10 , No. 2, Tahun 2019

P ISSN: 2086-1249 ; E ISSN: 2442-8922

\title{
PROFITABILITY, CAPITAL STRUCTURE AND ALLOCATION OF CORPORATE SOCIAL RESPONSIBILITY (CSR) FUNDS TO CORPORATE VALUES IN BASIC INDUSTRIAL AND CHEMICAL INDUSTRY COMPANIES IN INDONESIA
}

\author{
Indah Yuliana \\ Universitas Islam Negeri Maulana Malik Ibrahim Malang, Jl. Gajayana No. 50 Malang, \\ 65144, Indonesia \\ e-mail :indahoty@manajemen.uin-malang.ac.id
}

\begin{abstract}
Business organizations have the goal of maximizing company value. The era of new developments in management and corporate management shifts efforts to build value based on stakeholder-based strategies, namely to build the value of the company while taking into account and paying attention to stakeholder interests in the framework of achieving company goals. The legitimacy of the company in the eyes of stakeholders can be done with the integrity of the implementation of ethics in doing business and increasing corporate social responsibility. The purpose of this study is (1) to analyze the effect of profitability, capital structure and CSR fund allocation on firm value, (2) to analyze the moderation of Corporate Social Responsibility budget allocation variables to the relationship of profitability and capital structure to firm value. This study uses a quantitative approach using statistical tools and hypothesis testing. The population of this study is 65 basic industrial and chemical sector companies in Indonesia which are listed on the Indonesia Stock Exchange (IDX). The sampling technique was done by purposive sampling, data analysis using multiple linear regression analysis and moderation regression. The results of the study showed (1) Profitability directly had a significant effect on firm value while the capital structure and CSR fund allocation directly did not affect the firm value (2) Allocation of CSR funds strengthened the influence of capital structure on firm value. This shows that large debt does not affect investors to keep investing in the company, only investors are interested in the allocation of corporate social responsibility funds issued by the company, so that corporate social responsibility funds can be profitable for investors.

Keywords: capital structure, profitability, firm value and CSR fund allocation
\end{abstract}

\section{INTRODUCTION}

Company value is a reflection of the achievement of company performance that can affect investors' perceptions of the company. Dominick (2005) states that the purpose of establishing a company is to maximize the wealth or value of the company. The right proportion of liabilities and equity will encourage the highest shareholder value. Modigliani and Miller (1958) submitted the first proposal explaining that perfect capital markets assume no taxes and no transaction costs, investors will have the same expectations. Thus, the capital structure does not affect the cost of capital or company value. In (1963), Modigliani and Miller submitted a second proposal stating that interest 
Indah Yuliana : Profitability, Capital Structure and Allocation of Corporate Social Responsibility (CSR) Funds to Corporate Values in Basic Industrial and Chemical Industry Companies in Indonesia

payments would reduce the company's base to pay taxes. So, the cost of debt is lower than the cost of equity because interest payments reduce taxable income. Taxes encourage the value of companies with debt higher than the value of the same company without obligation.

Trade-off theory (Myers, 1984) states that the right capital structure is useful to increase capital from liabilities as a tax shield and reduce agency costs from careful operations of directors because companies have an obligation to pay principal and interest. The company determines the proportion of liabilities in its capital structure and will try to move gradually towards that target. Trade Off explains that an increase in company value is due to the position of the capital structure below the optimal point and the addition of debt. Conversely, a decrease in the value of the company caused by the position of capital structure is above the optimal point.

Hamidy (2015) states that debt will increase the value of the company, and increase the value of this company is greater if the debt can increase the profitability of the company. Ogbulu, et al (2012) and Kusumajaya (2011) found the capital structure had a positive effect on firm value. While the research of Dewi and Wirajaya (2013) suggested that the capital structure had a negative and not significant effect on firm value. The pecking order theory, introduced by Myers and Majluf (1984), explains that there is asymmetrical information between managers and investors regarding corporate investment opportunities. For new capital, directors are happy to obtain capital from internal capital sources, such as profits and cash flows that are still must be paid, who will not experience difficulties with an asymmetrical view of outside information. If there is insufficient source of capital in the internal company, the directors will obtain capital from liabilities and buy new common shares as a last resort.

The development of a level of awareness and public debate opens up opportunities for increasing demands on business commitments to contribute to sustainable economic development, through working with employees and their representatives, their families, local communities and the general public to improve the quality of life in ways that benefit both businesses alone or for 
Indah Yuliana : Profitability, Capital Structure and Allocation of Corporate Social Responsibility (CSR) Funds to Corporate Values in Basic Industrial and Chemical Industry Companies in Indonesia

development. Corporate Social Responsibility is the awareness that companies not only have economic and legal obligations to shareholders, but also have social obligations to stakeholders (stakeholders) such as government, customers, investors, society, employees and even competitors.

The form of company contributions can be in the form of programs that can increase community welfare, provide scholarships, improve infrastructure, including maintaining healthy and balanced natural environment (Fauziah, 2016). Wibisono (2007) states that corporate social responsibility has benefits to improve the company's reputation, maintain the image and strategy of the company. Freeman and Reed. Belkaoui and Karpik, Deegan, Steiner and Steiner stated that, an operational strategy that places a balance between the interests of the company and the interests of society and the environment, will bring value to the company both social (social value), and economic (economic value) and (environmental value ) The results of research by Chen and Lee (2017) show that the value of the company is related to corporate social responsibility.

Investment in corporate social responsibility, will increase the ratio of institutional shareholders, and expanding the scale of the company can lead to profit growth, which increases the value of the company. In addition to the form of caring for the community, corporate social responsibility (CSR) is one of the strategies implemented by the company to maintain the company, by collaborating and maintaining good relations with stakeholders and shareholders' interest groups (Irawan, 2016). The purpose of this study is to analyze the effect of profitability and capital structure on firm value, (2) Analyze the moderation of Corporate Social Responsibility budget allocation variables to the relationship of profitability and capital structure to firm value.

\section{THEORITICAL REVIEW}

\section{Capital Structure Theory}

Modigliani and Miller (1958) proposed that in a perfect capital market that assumes no tax and no transaction costs, investors will have the same expectations. Thus, the capital structure does not affect the cost of capital or 
Indah Yuliana : Profitability, Capital Structure and Allocation of Corporate Social Responsibility (CSR) Funds to Corporate Values in Basic Industrial and Chemical Industry Companies in Indonesia

company value. In (1963), Modigliani and Miller submitted a second proposal explaining that interest payments would reduce the company's base to pay taxes. So, the cost of debt is lower than the cost of equity because interest payments reduce taxable income. Taxes encourage the value of companies with debt higher than the value of the same company without obligation. Tax benefits derived from liabilities produce an optimal capital structure theory, which shows that there is an implicit optimal capital structure and that the capital structure influences the value of the company.

\section{Trade-Off Theory}

The trade-off theory (Myers, 1984) states that the right capital structure is useful to increase capital from liabilities as a tax shield and reduce agency costs from careful operations of directors because the company has an obligation to pay principal and interest. If the company cannot pay its debt, it might be forced to go bankrupt. This situation means reducing the free cash flow for directors without increasing the value of the company. The Trade Off theory explains that an increase in company value is due to the position of the capital structure below the optimal point and the addition of debt. Conversely, a decrease in company value caused by the position of capital structure is above the optimal point.

\section{Pecking Order Theory}

Myers and Majluf (1984) suggested preferences in choosing funding sources for companies. The first, namely using own capital, both retained earnings, third debt, and the last use of external funds. Profitable companies generally borrow a small amount, because they require little external financing. Companies that are less profitable tend to have greater debt because of internal funds that do not cover the needs and the debt arena is the preferred external source. External funds are preferred in the form of debt rather than own capital because of consideration of cheaper long-term debt issuance costs compared to share issuance costs. 
Indah Yuliana : Profitability, Capital Structure and Allocation of Corporate Social Responsibility (CSR) Funds to Corporate Values in Basic Industrial and Chemical Industry Companies in Indonesia

\section{Legitimacy Theory}

Community legitimacy is a strategic factor for companies in order to develop the company in the future. That, can be used as a vehicle to construct the company's strategy, in an effort to position itself in an increasingly advanced community environment. O'Donovan (2002) argues that the organization's legitimacy can be seen as something that is given by the community to the company and something that the company wants or wants from the community. Thus, legitimacy is a benefit or potential resource for the company to survive (going corner). Patten (1992) states that efforts that need to be carried out by companies in order to manage legitimacy to be effective, namely by: (1) Identifying and communicating / dialogue with the public, (2) Carrying out communication dialogues on issues of social and environmental values, and build perceptions about the company, (3) Conduct legitimacy and disclosure strategies, especially related to social responsibility issues

\section{Stakeholder Theory}

The company cannot break away from the surrounding social environment. The company should reduce the expectation gap with the surrounding community in order to increase the legitimacy of the community. For this reason, companies should maintain their reputation by shifting the pattern of orientation (goal) that was originally measured solely by economic measurement that tends to shareholder orientation, towards the stakeholder orientation by taking into account social factors as a manifestation of concern and alignment with the social problem ( stakeholder orientation) (Hadi. 2011: 95). The company maintains the legitimacy of stakeholders and occupies it within the framework of policy and decision making, so that it can support the achievement of company goals, namely business stability and going concern guarantees (Adam. C. H, 2002) 
Indah Yuliana : Profitability, Capital Structure and Allocation of Corporate Social Responsibility (CSR) Funds to Corporate Values in Basic Industrial and Chemical Industry Companies in Indonesia

\section{Preparation of Hypotheses}

\section{Relationship between profitability and company value}

One important indicator for investors in assessing company prospects in the future is to see how far the company's ability to generate profits is growing. The better the growth of the company's ability to generate profits, the better prospects for the company in the future (Awalludin, 2017). Research results of William, et al (2016); Dea (2017) shows that a company's ability to generate profits has a positive impact on company value. The company's ability to generate profits will increase the value of the company and will attract investors to invest in the company. Based on the description above can be concluded with the hypothesis:

H1: Profitability has an influence on company value.

\section{Relationship of capital structure with company value}

Trade-off theory (Myers, 1984) states that the right capital structure is useful to increase capital from liabilities as a tax shield and reduce agency costs from careful operations of directors because companies have an obligation to pay principal and interest. The company determines the proportion of liabilities in its capital structure and will try to move gradually towards that target. Trade Off explains that an increase in company value is due to the position of the capital structure below the optimal point and the addition of debt. Conversely, a decrease in the value of the company caused by the position of capital structure is above the optimal point. Hamidy (2015) states that debt will increase the value of the company, and increase the value of this company is greater if the debt can increase the profitability of the company. Ogbulu, et al (2012) and Kusumajaya (2011) found the capital structure had a positive effect on firm value. While the research of Dewi and Wirajaya (2013) suggested that the capital structure had a negative and not significant effect on firm value.

$\mathrm{H} 2$ : Capital structure affects the value of the company 
Indah Yuliana : Profitability, Capital Structure and Allocation of Corporate Social Responsibility (CSR) Funds to Corporate Values in Basic Industrial and Chemical Industry Companies in Indonesia

Relationship between Allocation of Corporate Social Responsibility (CSR) funds, Profitability, capital structure and company value

The development of a level of awareness and public debate opens up opportunities for increasing demands on business commitments to contribute to sustainable economic development, through working with employees and their representatives, their families, local communities and the general public to improve the quality of life in ways that benefit both businesses alone or for development. The form of company contributions can be in the form of programs that can increase community welfare, provide scholarships, improve infrastructure, including maintaining healthy and balanced natural environment (Fauziah, 2016). Wibisono (2007) states that corporate social responsibility has benefits to improve the company's reputation, maintain the image and strategy of the company. Freeman and Reed. Belkaoui and Karpik, Deegan, Steiner and Steiner stated that, an operational strategy that places a balance between the interests of the company and the interests of society and the environment, will bring value to the company both social (social value), and economic (economic value) and (environmental value ) The results of research by Chen and Lee (2017) show that the value of the company is related to corporate social responsibility. Investment in corporate social responsibility, will increase the ratio of institutional shareholders, and expanding the scale of the company can lead to profit growth, which increases the value of the company.

H3: Corporate Social Responsibility (CSR) funds affect the relationship of profitability with company value

H4: Corporate Social Responsibility (CSR) funds affect the relationship of capital structure with company value

\section{RESEARCH METHODS}

This study uses a quantitative approach using statistical tools and hypothesis testing. The population of this study is the basic industrial and chemical sector companies listed on the Indonesia Stock Exchange. Sampling using purposive 
Indah Yuliana : Profitability, Capital Structure and Allocation of Corporate Social Responsibility (CSR) Funds to Corporate Values in Basic Industrial and Chemical Industry Companies in Indonesia

sampling and obtained 15 research samples. Companies that are used as research samples are as follows:

Table 1. Research Sample

\begin{tabular}{|c|l|}
\hline No & \multicolumn{1}{|c|}{ Company } \\
\hline 1 & PT Semen Baturaja \\
\hline 2 & PT Indopoly Swakarsa Industry \\
\hline 3 & PT Charoen Pokphand Indonesia \\
\hline 4 & PT Semen Indonesia \\
\hline 5 & PT Wijaya Karya Beton \\
\hline 6 & PT Asahimas Flat Glass \\
\hline 7 & PT Lion Metal Works \\
\hline 8 & PT Duta Pertiwi Nusantara \\
\hline 9 & PT Surya Toto Indonesia \\
\hline 10 & PT Indo Acidatama \\
\hline 11 & PT Budi Starch \& Sweetener \\
\hline 12 & PT Argha Karya Prima \\
\hline 13 & PT Candra Asri Petrochemical \\
\hline 14 & PT Argha Karya Prima Industry \\
\hline 15 & PT Ekadharma International \\
\hline & \\
\hline
\end{tabular}

This study uses secondary data in the form of company annual reports and corporate social responsibility fund allocation of companies obtained on the IDX website www.idx.co.id. The observation period is 3 years (2014-2016) in the basic industrial and chemical manufacturing companies listed on the IDX. The independent variable in this study is profitability which is proxied by Return On Assets (ROA), Return On Equity (ROE) and Net Profit Margin (NPM) and the capital structure is proxied by Debt to equity ratio, Debt to asset ratio, Equity to asset ratio. The dependent variable in this study is the firm value that is proxied by Price to Book Value (PBV). Variables that strengthen or weaken (moderating) in this study are funds for corporate social responsibility (CSR). Testing the 
Indah Yuliana : Profitability, Capital Structure and Allocation of Corporate Social Responsibility (CSR) Funds to Corporate Values in Basic Industrial and Chemical Industry Companies in Indonesia

hypothesis by using (1) test the Determination Coefficient, (2) T (T-test), (3) Test the Moderated Regression Analysis (MRA).

\section{Hasil Penelitian}

\section{Uji Hipotesis}

Tabel 2. Durbin-Watson test result

\begin{tabular}{|c|c|c|c|c|c|}
\hline Model & $\mathrm{R}$ & $\begin{array}{c}\mathrm{R} \\
\text { Square }\end{array}$ & $\begin{array}{c}\text { Adjusted R } \\
\text { Square }\end{array}$ & $\begin{array}{l}\text { Std Error of } \\
\text { the Estimate }\end{array}$ & Durbin-Watson \\
\hline 1 & .761 & .579 & .499 & .27426 & 2.129 \\
\hline
\end{tabular}

a. Predictors: (Constant), CSR, DAR,ROE,EAR,NPM,DER,ROA

b. Dependent Variable: PBV

Based on the analysis that has been done, the adjusted $\mathrm{R}$ Square value is 0.579 or $57.9 \%$, which means that the company's value variable proxied by using PBV can be explained by ROA, ROE, NPM, DER, DAR and EAR, and the remaining $42.1 \%$ explained by other variables outside the equation.

Table 3. T test result

Coefficients

\begin{tabular}{|c|c|c|c|c|c|}
\hline \multirow[t]{2}{*}{ Model } & \multicolumn{2}{|c|}{$\begin{array}{l}\text { Unstandardized } \\
\text { Coefficients }\end{array}$} & \multirow{2}{*}{\begin{tabular}{|c|}
$\begin{array}{l}\text { Standardized } \\
\text { Coefficients }\end{array}$ \\
Beta
\end{tabular}} & \multirow[b]{2}{*}{$\mathrm{t}$} & \multirow[b]{2}{*}{ Sig. } \\
\hline & B & Std.Error & & & \\
\hline 1 (Constant) & -.318 & .091 & & -3.499 & .001 \\
\hline ROA & .622 & .117 & .630 & 5.314 & .000 \\
\hline $\mathrm{ROE}$ & .782 & .130 & .676 & 6.008 & .000 \\
\hline NPM & .382 & .113 & .457 & 3.370 & .002 \\
\hline DER & -.099 & .169 & -.089 & -.583 & .563 \\
\hline DAR & -.054 & .228 & -.036 & -.237 & .814 \\
\hline EAR & .426 & .519 & .124 & .821 & .416 \\
\hline
\end{tabular}

a. Dependent Variable : PBV 
Indah Yuliana : Profitability, Capital Structure and Allocation of Corporate Social Responsibility (CSR) Funds to Corporate Values in Basic Industrial and Chemical Industry Companies in Indonesia

From the table above shows that profitability (ROA, ROE and NMP) has a positive and significant influence on firm value while capital structure (DER, DAR and EAR) does not have a significant effect on firm value

Table 4. Moderation Result of ROA Variable Test

Coefficients

\begin{tabular}{|c|c|c|c|c|c|}
\hline \multirow[t]{2}{*}{ Model } & \multicolumn{2}{|c|}{$\begin{array}{c}\text { Unstandardized } \\
\text { Coefficients }\end{array}$} & \multirow{2}{*}{$\begin{array}{l}\text { Standardized } \\
\text { Coefficients } \\
\text { Beta }\end{array}$} & \multirow[b]{2}{*}{$\mathrm{t}$} & \multirow[b]{2}{*}{ Sig. } \\
\hline & B & Std.Error & & & \\
\hline $1 \quad$ (Constant) & -3.879 & 2.298 & & -1.688 & .099 \\
\hline ROA & 1.201 & .379 & 1.216 & 3.167 & .003 \\
\hline CSR & 2.651 & 1.714 & .240 & 1.546 & .130 \\
\hline $\mathrm{ROA}^{*} \mathrm{CSR}$ & -.002 & .002 & -.591 & -1.563 & .126 \\
\hline
\end{tabular}

Table 5. Moderation Result of ROE Variable Test Coefficients

\begin{tabular}{|c|c|c|c|c|c|}
\hline \multirow[t]{2}{*}{ Model } & \multicolumn{2}{|c|}{$\begin{array}{c}\text { Unstandardized } \\
\text { Coefficients }\end{array}$} & \multirow{2}{*}{$\begin{array}{l}\text { Standardized } \\
\text { Coefficients } \\
\text { Beta }\end{array}$} & \multirow[b]{2}{*}{$\mathrm{t}$} & \multirow[b]{2}{*}{ Sig. } \\
\hline & B & Std.Error & & & \\
\hline 1 (Constant) & -3.179 & 2.090 & & -1.521 & .136 \\
\hline $\mathrm{ROE}$ & 1.413 & .425 & 1.221 & 3.324 & .002 \\
\hline CSR & 1.777 & 1.505 & .161 & 1.180 & .245 \\
\hline $\mathrm{ROE}^{*} \mathrm{CSR}$ & -.002 & .001 & -.568 & -1.547 & .130 \\
\hline
\end{tabular}


Indah Yuliana : Profitability, Capital Structure and Allocation of Corporate Social Responsibility (CSR) Funds to Corporate Values in Basic Industrial and Chemical Industry Companies in Indonesia

Table 6 . Moderation Result of NPM Variable Test Coefficients

\begin{tabular}{|c|c|c|c|c|c|}
\hline \multirow[t]{2}{*}{ Model } & \multicolumn{2}{|c|}{$\begin{array}{l}\text { Unstandardized } \\
\text { Coefficients }\end{array}$} & \multirow{2}{*}{$\begin{array}{l}\text { Standardized } \\
\text { Coefficients } \\
\text { Beta }\end{array}$} & \multirow[b]{2}{*}{$\mathrm{t}$} & \multirow[b]{2}{*}{ Sig. } \\
\hline & B & Std.Error & & & \\
\hline 1 (Constant) & -.623 & .091 & & -.255 & .800 \\
\hline NPM & .306 & .117 & .366 & 1.162 & .252 \\
\hline CSR & .324 & .130 & .029 & .177 & .860 \\
\hline $\mathrm{NPM}^{*} \mathrm{CSR}$ & .000 & .001 & .114 & .368 & .715 \\
\hline
\end{tabular}

Table 7. Moderation Result of DER Variable Test Coefficients

\begin{tabular}{|c|c|c|c|c|c|}
\hline \multirow[t]{2}{*}{ Model } & \multicolumn{2}{|c|}{$\begin{array}{c}\text { Unstandardized } \\
\text { Coefficients }\end{array}$} & \multirow{2}{*}{$\begin{array}{l}\text { Standardized } \\
\text { Coefficients } \\
\text { Beta }\end{array}$} & \multirow[b]{2}{*}{$\mathrm{t}$} & \multirow[b]{2}{*}{ Sig. } \\
\hline & B & Std.Error & & & \\
\hline 1 (Constant) & -3.557 & 2.410 & & -1.476 & .148 \\
\hline DER & 1.024 & .384 & .920 & 2.664 & .011 \\
\hline CSR & 3.455 & 1.943 & .312 & 1.778 & .083 \\
\hline $\mathrm{DER}^{*} \mathrm{CSR}$ & -.042 & .013 & -1.191 & -3.188 & .003 \\
\hline
\end{tabular}

Table 8. Moderation Result of DAR Variable Test Coefficients

\begin{tabular}{|c|c|c|c|c|c|}
\hline \multirow[t]{2}{*}{ Model } & \multicolumn{2}{|c|}{$\begin{array}{l}\text { Unstandardized } \\
\text { Coefficients }\end{array}$} & \multirow{2}{*}{$\begin{array}{l}\text { Standardized } \\
\text { Coefficients } \\
\text { Beta }\end{array}$} & \multirow[b]{2}{*}{$\mathrm{t}$} & \multirow[b]{2}{*}{ Sig. } \\
\hline & B & Std.Error & & & \\
\hline 1 (Constant) & -2.969 & 2.658 & & -1.117 & .270 \\
\hline DAR & 1.503 & .716 & 1.006 & 2.101 & .042 \\
\hline CSR & 3.605 & 2.382 & .326 & 1.513 & .138 \\
\hline $\mathrm{DAR}^{*} \mathrm{CSR}$ & -.122 & .054 & -1.170 & -2.282 & .028 \\
\hline
\end{tabular}


Indah Yuliana : Profitability, Capital Structure and Allocation of Corporate Social Responsibility (CSR) Funds to Corporate Values in Basic Industrial and Chemical Industry Companies in Indonesia

Table 9. Moderation Result of EAR Variable Test Coefficients

\begin{tabular}{|c|c|c|c|c|c|}
\hline \multirow[t]{2}{*}{ Model } & \multicolumn{2}{|c|}{ Coefficients } & $\begin{array}{l}\text { Standardized } \\
\text { Coefficients }\end{array}$ & \multirow[b]{2}{*}{$\mathrm{t}$} & \multirow[b]{2}{*}{ Sig. } \\
\hline & B & Std.Error & Beta & & \\
\hline 1 (Constant) & -5.545 & 3.654 & & -1.518 & .137 \\
\hline EAR & 8.790 & 4.258 & 2.563 & 2.064 & .045 \\
\hline CSR & 8.497 & 4.617 & .768 & 1.840 & .073 \\
\hline EAR*CSR & -.280 & .142 & -2.356 & -1.979 & .055 \\
\hline
\end{tabular}

\section{DISCUSSION}

\section{Effect of Profitability on Company Values}

The results of the analysis state that the three proxies (ROA, ROE, NMP) of profitability variables have a positive and significant effect on firm value. The better the growth of profitability means the prospect of the company in the future is considered to be better too, meaning that the better the value of the company in the eyes of investors. If the company's ability to generate profits increases, then the stock price will also increase (Husnan, 2005). The results of this study are in line with the results of Yuliana (2009), Sri Hermunighsih (2009), Zulfia Eka Sari (2013), Ayu Sri and Ari (2013), Werner R. Murhadi (2008), Gill and Obradovich (2012), Sujoko and Soebiantoro (2007) states that profitability affects the value of the company.

Tandelilin (2001: 240) states that one important indicator for investors in assessing company prospects in the future is to see the extent to which the company's growth ability in generating profits. The greater the ability of the company to generate profits from the management of assets it has shows the more efficient use of resources owned by the company. So that this will increase the value of the company. Susilaningrum (2016) explains that the greater the company's ability to generate profits with the management of assets it has will increase the value of the company. Likewise the higher Return on Equity (ROE) shows the more efficient the company in using its own capital to generate investor profits planted in the company (Horne and John, 2005) and high ROE 
Indah Yuliana : Profitability, Capital Structure and Allocation of Corporate Social Responsibility (CSR) Funds to Corporate Values in Basic Industrial and Chemical Industry Companies in Indonesia

indicates that the company has good prospects in the future. The profit potential reflected in the ROE ratio will increase investor confidence in stock demand (Yuliana, 2013) so that it will increase the value of the company. Net profit margin reflects the efficiency of all parts, namely production, personnel, marketing, and finance within the company.

The results of this study support Munawaroh's (2014) research showing that the increasing value of NPM will give an indication of good company prospects so that it can trigger investors to participate in increasing demand for shares which will have implications for increasing corporate value. High company value illustrates that the company's performance is in good condition and can show optimal profitability so that it can benefit the company.

\section{Effect of Capital Structure on Firm Value}

The results of the analysis state that the three proxies of the capital structure variable (DER, DAR, EAR)) have no effect on firm value. Sudana (2009: 23) states that the greater this ratio shows the portion of debt usage in financing investments in assets is greater, this results in increased financial risk. Companies that have high debt will have a greater risk of loss. Unfavorable or negative debt occurs when the company does not have as much yield as a fixed funding cost. But there is also a chance to get a big profit. Conversely, if the company has a lower debt ratio, it certainly has a lower risk of loss, especially when the economy declines. This impact also results in a low rate of return on high economies (Kasmir, 2008). Companies must know or be sensitive to the business climate because the use of debt can also provide profits or losses to the company. Financial leverage is the use of funds which causes the company to bear a fixed burden in order to increase or optimize revenue per share. If the return on assets is greater than the cost of debt, then the leverage is profitable and returns on capital with this return also increase. Vice versa if the return on assets is smaller than the cost of debt, then leverage will reduce the return on capital (Irawati, 2006). Debt has no effect on the high and low value of the company, if the interest costs charged do not exceed the benefits provided from the debt used. The results 
Indah Yuliana : Profitability, Capital Structure and Allocation of Corporate Social Responsibility (CSR) Funds to Corporate Values in Basic Industrial and Chemical Industry Companies in Indonesia

of this study support the results of Apsari (2015) study which shows that companies with stable earnings and sales can safely use larger amounts of debt because they do not have a greater chance of bankruptcy compared to companies with profit and sales that tend not to stable.

\section{The Effect of Corporate Social Responsibility Fund Allocation as a Moderating} Variable in the relationship between Profitability and Corporate Value

The test results show that Corporate Social Responsibility Fund Allocation variables cannot moderate the relationship between profitability and company value. The allocation of Corporate Social Responsibility funds is not able to increase the value of the company when the company's profitability is high, and conversely the Corporate Social Responsibility fund allocation is not able to increase the value of the company when the company's profitability is low. Investors do not respond well to spending on Corporate Social Responsibility funds with high profitability. The amount of corporate social responsibility funds cannot strengthen or weaken the relationship of profitability to company value. Investors consider that the allocation of funds for Corporate Social Responsibility has social, environmental and economic relations so that there is no relationship related to the level of profit to the company. That is, the allocation of funds for corporate social responsibility cannot strengthen or weaken the relationship of profitability to company value. The partial assumption that Corporate Social Responsibility (CSR) is a philanthropic activity regulated by law, makes the growing assumption that Corporate Social Responsibility (CSR) is an activity that has no connection with the company's core business, waste and only imaging activities for Corporate Social Responsibility (CSR) considered as a cost that does not clearly have financial benefits. Doubts about the financial benefits of Corporate Social Responsibility (CSR), unclear provisions and law enforcement and hopes of society and government for CSR practices foster doubts about how Corporate Social Responsibility (CSR) must be run and underlying motivation so that the development of CSR organizations is only a template, not related to core business and Corporate Social Responsibility (CSR) seen for certain companies 
Indah Yuliana : Profitability, Capital Structure and Allocation of Corporate Social Responsibility (CSR) Funds to Corporate Values in Basic Industrial and Chemical Industry Companies in Indonesia

only. When referring to the definition of Corporate Social Responsibility (CSR) in various existing legal provisions, the legal provisions of Corporate Social Responsibility (CSR) have degraded the characteristics of Corporate Social Responsibility (CSR). This can be seen from the lack of clarity of the meaning of "natural resources" and what types of companies must carry out Corporate Social Responsibility (CSR) activities. Carroll places economic responsibility in the first place, in fact contrary to the fact that a company must pay attention to legal provisions before carrying out its business activities Legal provisions are a minimum written social contract between the company and the community.

The Effect of Corporate Social Responsibility Fund Allocation as a Moderating Variable in the relationship between Capital Structure and Corporate Value

The test results show that CSR fund variables (moderating variables) interact with capital structure variables (independent variables) but are not significantly related to firm value variables (dependent variable) then the $Z$ variable (CSR) is a pure moderator variable (pure moderator). Corporate Social Responsibility has benefits to improve the company's reputation, maintain the image and strategy of the company (Wibisono, 2007). With social responsibility through various CSR fund allocations in social activities, the company shows its moral commitment not to do certain business activities that can harm the interests of the wider community. The company feels cared, has responsibility for the community and thus will prevent it from harming the community through certain business activities so that the company will be more accepted in the community. This in turn will make the community feel they own the company, and can create a social and political climate that is safer, conducive, and profitable for the company's business activities. The company's involvement in various social activities also finally had a positive and beneficial impact on the company's business continuity in the community.

Corporate Social Responsibility (CSR) is a corporate strategy phenomenon that accommodates the needs and interests of its stakeholders. CSR arises since an era where awareness of the sustainability of long-term companies is more 
Indah Yuliana : Profitability, Capital Structure and Allocation of Corporate Social Responsibility (CSR) Funds to Corporate Values in Basic Industrial and Chemical Industry Companies in Indonesia

important than just profitability. CSR in carrying out its social responsibilities, focuses its attention on three things, namely profit (profit), society (people), and environment (planet). Companies must have an adequate level of profitability, because profits are the foundation for companies to be able to develop and maintain their existence. With sufficient profit, the company can divide dividends to shareholders, provide appropriate compensation to employees, allocate a portion of the profits earned for future business growth and development, pay taxes to the government, and provide many expected impacts on society. By paying attention to the community, companies can contribute to improving the quality of life of the community. Attention to the community can be done by means of companies carrying out activities and making policies that can improve the welfare, quality of life and competence of people in various fields. By paying attention to the environment, companies can participate in environmental conservation efforts to maintain the quality of life in the long term long.

The involvement of companies in the maintenance and preservation of the environment means that companies participate in efforts to prevent disasters and minimize the impact of disasters caused by environmental damage. By carrying out social responsibility, the company is expected to not only pursue short-term profits, but also contribute to improving the quality of life of the community and the environment (especially environment) in the long run. The results of the Pijourlet study (2013) show that the company determines to a certain extent financing decisions in accordance with the level of corporate social responsibility, social and environmental performance. Socially responsible companies are aware of the benefits for them to issue equity more frequently and in greater amounts, due to a reduction in information asymmetry and lower capital costs. Brigham and Houston (2008) say that companies with high returns on investment use relatively small debt. High rates of return allow companies to finance most of the funding needs with funds generated internally. Profitability also has an important meaning in an effort to maintain its survival in the long term, because profitability shows whether the company has good prospects in the future. 
Indah Yuliana : Profitability, Capital Structure and Allocation of Corporate Social Responsibility (CSR) Funds to Corporate Values in Basic Industrial and Chemical Industry Companies in Indonesia

\section{CONCLUSION}

1. Based on the results of the study, the following conclusions are drawn:

2. Profitability directly and significantly affects the value of the company

3. Capital structure directly does not affect the value of the company.

4. Variable allocation of CSR funds cannot influence the effect of profitability on firm value. Fund allocation for Corporate Social Responsibility is not able to increase the value of the company when the profitability of the company is high, and vice versa Fund allocation for Corporate Social Responsibility is not able to increase the value of the company when the profitability of the company is low.

5. Variable allocation of CSR funds strengthens the influence of capital structure on firm value. This shows that the large debt does not affect investors to keep investing in the company, it's just that investors are interested in the corporate social responsibility fund allocation issued by the company, therefore the funds for corporate social responsibility can be beneficial for investors.

\section{SUGGESTION}

Based on the results of the study, the authors provide recommendations as follows:

1. Further research is expected to be able to add other variables, not only profitability and capital structure or indicators. Addition of samples and longer years of research.

2. For investors the results of research related to profitability and capital structure need to be reviewed, so that investors can be more observant about the extent of the company's development and can compare with other companies.

3. For companies that are classified as companies that issue a lot of waste impacts, they should pay more attention to the surrounding environment so that interested investors and corporate social responsibility funds as a moderating variable issued can still be maximized and image. 
Indah Yuliana : Profitability, Capital Structure and Allocation of Corporate Social Responsibility (CSR) Funds to Corporate Values in Basic Industrial and Chemical Industry Companies in Indonesia

\section{BIBLIOGRAPHY}

Adam, C.A. 2002. International organizational factors influencing corporate sosial dan ethical reporting: beyond current theorising. Accounting, auditing,accountability, Vol. 15 no. 2 pp: 22-50.

Belkaoui. A, dan Karpik. P.G. 1989. Determinants of the corporate decision to disclose social information. Accounting, Auditing, dan Accountability Journal. Vol. 2. No. 1, pp: 36-51

Chen, Roger., Lee, Chen-Hsun (2017). The influence of CSR on firm value: an applicationof panel smooth transition regression on Taiwan. Applied Economic, 49, (34), 3422-3434

Deegan.C, dan Tobin.R.M.2002.An examination of the corporate sosial dan environmental disclosures a theoritical foundation. Accounting, Auditing dan Accountability Journal, Vol 15 No 3 pp:312-343

Dewi, Ayu Sri Mahatma., Wirajaya, Ary. (2013). Pengaruh Struktur Modal, Profitabilitas dan Ukuran Perusahaan Pada Nilai Perusahaan. E-Journal Akuntansi Universitas Udayana, ISSN: 2302-8556.

Freeman, R. E,1984, Strategic Management: A Stakeholders Approach, Marshall, Cambridge

Freeman, R.E., \& Reed. 1983. Stockholders and Stakeholders: a New Perspective on Corporate Governance. Californian Management Review, Vol 25. No. 2. pp. 88-106.

George A, Arkelov (1970). The Market for "Lemons": Quality Uncertainly and The Market Mechanism. Oxford University Press. The Quarterly Journal Of Economics. Vol. 84, No. 3, pp. 488-500

Hadi, Nur. 2011. Corporate Social Responsibility.Yogyakarta: Graha Ilmu .

Hamidy, Rusdi. 2014. Pengaruh Struktur Modal Terhadap Nilai Perusahaan dengan Profitabilitas Sebagai Variabel Intervening Pada Perusahaan Property dan Real Estate di Bursa EfekIndonesia. Tesis. Universitas UdayanaHalim, Abdul (2015). Analisis Investasi di Aset Keuangan. Jakarta : Mitra Wacana Media.

Horne, James Van dan John Wachowicz. 2015. Prinsip-prinsip Manajemen Keuangan. Jakarta: Salemba Empat.

Irawan, bambang. 2016. Pengaruh Leverage Level, Firm Size, Profitabilitas, dan Deviden Terhadap Corporate Social Responsibility (CSR)

Kasmir (2010). Pengantar Manajemen Keuangan. Jakarta : Pernadamedia Group. 
Indah Yuliana : Profitability, Capital Structure and Allocation of Corporate Social Responsibility (CSR) Funds to Corporate Values in Basic Industrial and Chemical Industry Companies in Indonesia

Kusumajaya, Dewa Kadek Oka. (2011). Pengaruh Struktur Modal dan Pertumbuhan Perusahaan Terhadap Profitabilitas dan Nilai Perusahaan Pada Perusahaan Manufaktur di Bursa Efek Indonesia, Tesis (tidak dipublikasikan). Program Pascasarjana Universitas Udayana, Denpasar.

Modigliani, F. Dan Miller, M. H. 1958. The cost of capital, corporate finance dan the theory of investment. American Economic Review, Vol 48 pp: 261-297.

Modigliani, F. Dan Miller, M. H. 1963. Corporate income taxes dan the cost of capital: a correction. American Economic Review, Vol 53 pp: 433-43.

Munawaroh, Aisyatul., Priyadi, Maswar Patuh. (2014). Pengaruh Profitabilitas Terhadap Nilai Perusahaan dengan Corporate Social Responsibilitysebagai Variabel Moderating. Jurnal Ilmu \& Riset Akuntansi, 3 (4), 1-17.

Myer. S.C. 1984, The Capital Strukture Puzzle. The Journal of Finance, Vol. 39, No. 3, Papers dan Proceedings, Forty-second Annual Meeting, American FinanceAssosiation, San Francisco, CA, desember 28-30, 1983, pp. 575-592.

O'donovan, Gary. (2002). Enviromental Disclosures in the Annual Report: Extending the Applicability and Predictive Power of Legitimacy Theory.Accounting, Auditing \& Accountability Journal, 15 (3) pp. 344371.

O'donovan, Gary. (2002). Enviromental Disclosures in the Annual Report: Extending the Applicability and Predictive Power of Legitimacy Theory.Accounting, Auditing \& Accountability Journal, 15 (3) pp. 344371.

Ogbulu, Onyemachi Maxwell. (2012). “ Capital Structure and Firm Value: Empirical Evidence from Nigeria". International journal of Business and Social Science, Vol 3 pp: 252-261.

Patten, D. M. 1992. Intra-industry environmental disclosures in response to the Alaskan oil spill: a note on legitimacy theory. Accounting, Organizations and Society, 17(5): 471-475.

Pijourlet, Guillaume. (2013). Corporate Social Responsibility and Financing Decisions, JEL classification: G32, M14.

Sudana, I Made (2009). Manajemen Keuangan. Teori dan Praktik. Surabaya : Airlangga University Press.

Tandelilin, Eduardus (2010).Portofolio dan Investasi Teori dan Aplikasi. Edisi Pertama. Yogyakarta : Kanisius. 
Indah Yuliana : Profitability, Capital Structure and Allocation of Corporate Social Responsibility (CSR) Funds to Corporate Values in Basic Industrial and Chemical Industry Companies in Indonesia

Yuliana, Indah (2010). Investasi. Produk Keuangan Syarih. Malang: UIN-MALIKI Press

Yuliana., Akbar, Dinnul Alfian., Aprillia, Rini. (2013). Pengaruh Struktur Modal dan Return OnEqueity (ROE) Terhadap Nilai Perusahaan. Jurnal ilmiah $\begin{array}{lllll}\text { forum bisnis } \& \quad \text { kewirausahaan, } 2 & \text { (2), } 14\end{array}$ 26.http://repository.umy.ac.id/bitstream/handle/123456789/8066/NAS KAH\%20PUBLIKASI\%20FAUZIAH\% 